\title{
Visual communication, reproductive behavior, and home range of Hylodes dactylocinus (Anura, Leptodactylidae)
}

\author{
Patrícia Narvaes and Miguel Trefaut Rodrigues \\ Departamento de Zoologia, Instituto de Biociências, Universidade de São Paulo, C.P. 11461, São Paulo-SP, 05422-970, \\ Brazil.E-mails: pnarvaes@yahoo.com, mturodri@usp.br.
}

\begin{abstract}
Visual communication, reproductive behavior, and home range of Hylodes dactylocinus (Anura, Leptodactylidae). We studied the signaling, reproductive and courtship behaviors of the diurnal stream-dwelling frog Hylodes dactylocinus. The repertoire of visual signals of $H$. dactylocinus includes foot-flagging, leg-stretching, body movements, and toe-wiggling. The visual signals are performed only by males and are used to defend territories against intruders and to attract females. Home range size varied from 0.12 to $13.12 \mathrm{~m}^{2}$ for males $(\mathrm{N}=44)$, and from 0.45 to $7.98 \mathrm{~m}^{2}$ for females $(\mathrm{N}=24)$; residency time varied from one to 12 months for males, and from two to 10 months for females. During the courtship of $H$. dactylocinus the male gives an encounter call towards an approaching female, touches her snout, and guides her to a previously dug nest. After oviposition, the female leaves the nest and returns to her own home range; the male remains calling after concealing the nest entrance.
\end{abstract}

Keywords: Anura, Leptodactylidae, Hylodinae, Hylodes dactylocinus, home range, reproductive behavior, visual communication, Atlantic Forest, southeastern Brazil.

\section{Introduction}

Although acoustic communication is widespread in nocturnal and diurnal frogs, visual displays have been frequently associated to diurnal species living in noisy habitats such as torrent streams (Heyer et al. 1990, Endler 1992, Lindquist and Hetherington 1996, Hödl et al. 1997, Hödl and Amézquita 2001). Visual signaling is often reported in agonistic contexts,

Received 14 February 2005.

Accepted 29 September 2005.

Distributed December 2005. sometimes associated with territorial defense (Richards and James 1992, Pombal et al. 1994, Lindquist and Hetherington 1996, Hödl et al. 1997), or courtship interactions (Wells 1980a, Harding 1982, Davison 1984, Zimmermann and Zimmermann 1988, Haddad and Giaretta 1999). Limb conveyed signals are the most distinctive and the most frequent form of visual display described so far (e.g., Harding 1982, Davison 1984, Heyer et al. 1990, Pombal et al. 1994). Some nocturnal species also present limb conveyed signals (Haddad and Giaretta 1999, Bertoluci 2002, Hartmann et al. 2004, 2005) but 
their larger and convergent occurrence in diurnal frogs lead to the idea that they evolved in species with diurnal habits (Harper 1991, Endler 1992).

The subfamily Hylodinae (Dubois 2005), a moderately diverse group of mostly diurnal leptodactylids living along mountain streams, currently comprises the genera Hylodes, Crossodactylus, and Megaelosia. The genus Hylodes presently assemblies 20 species (Frost 2004) and is endemic to the mountainous regions of southeastern Brazil. Although species of Hylodes are very common along forest streams, behavioral data are known only for a few of them (Heyer et al. 1990, Faria et al. 1993, Narvaes 1997, Hatano et al. 1998, Haddad and Giaretta 1999), and anecdotal life history information is available for a few species (Gouvêa 1979, Haddad and Pombal 1995, Haddad et al. 1996). Hylodes dactylocinus is the smallest known species of the genus and is restricted to the Serra dos Itatins, in the Atlantic Forest of southeastern Brazil (Pavan et al. 2001). In this paper we provide data on visual signaling, home range, and courtship behavior of this diurnal stream-dwelling frog.

\section{Material and Methods}

The study site was a $150 \mathrm{~m}$ transect of a mountain stream, about 2 to $7 \mathrm{~m}$ wide and 10 to $40 \mathrm{~cm}$ deep, at the Estação Ecológica JuréiaItatins (EEJI), Núcleo Arpoador, (2423’47” S, 4701'03” W), state of São Paulo, southeastern Brazil. The stream was located inside a primary forest, and it was shadowed, shallow, and characterized by the presence of small rocks, and by having only a few boulders scattered along it. At the EEJI, the dry season extends from April to October, and the rainy season from December to March. During the study the mean temperature in the area varied from 19.9 to $25^{\circ} \mathrm{C}$, and the total amount of rain in 1995 was $1.796 \mathrm{~mm}$ (data from DAEE Peruíbe-SP).

From October 1994 to December 1995 the study area was visited 15 times, totaling 130 days, usually between 7:00 to 17:00 h. The captured frogs were toe-clipped according to Hero (1989), measured (snout-vent length and tibia length) and weighed before released. A pelvic ring, made with a brown or white polyester line, with a combination of one or two colored beads (out of a set of ten different colors) were set to each previously marked frog to allow identification at distance. Sex was identified by presence of vocal sacs or color pattern. Pregnant females were also recognized by the presence of eggs visible through the transparent skin. Individuals with SVL $<23 \mathrm{~mm}$ and with a light brownish dorsum, lacking the adult color pattern, were considered juveniles. A total of 205 specimens were marked and released (74 adult males, 63 adult females, and 68 juveniles).

A grid was adopted to evaluate the home range of Hylodes dactylocinus by dividing the stream bed in one square meter plots, and creating a coordinate system where the $\mathrm{Y}$ axis points represented distances paralleling the stream bed, and the $\mathrm{X}$ axis those at right angles to the stream bed. The total marked area comprised approximately $835 \mathrm{~m}^{2}$. Data from frogs recaptured three or more times were used to calculate home range size by the Minimum Convex Polygon Method (Mohr 1947), with the McPAAL 1.1 program (micro-computer programs for the analysis of animal locations) excluding $5 \%$ of the external points.

Observations were made following the Focal-Animal Sampling Method in which all occurrences of specified actions of an individual, or group of individuals, were recorded during one hour (Altman 1974, Lehner 1979). Observations were tape-recorded and videotaped in the field. For underwater observations a common glass was used - the bottom of it was kept on the upper surface of the flowing water. By this means, it was possible to see clearly under water, without disturbing the diving animals. For the statistical analysis, we used the Mann-Whitney rank-sum test for the hypothesis of equality between males and females regarding 
number of recaptures, home range size and time of residency, and between number of eggs in right and left ovaries. The Pearson productmoment correlation was used to test the hypothesis of correlation between home range size and the variables SVL, time of residency, number of recaptures, and weight, for males and females. For all tests we adopted the significance level of 0.05 (Zar 1999).

\section{Results}

\section{Life History and Population Structure}

Hylodes dactylocinus is a small cryptically colored diurnal frog (mean adult male SVL = $25.2 \mathrm{~mm}$, mean adult female SVL $=27 \mathrm{~mm}$ ) found predominantly on emerged rocks along streams. They are wary and difficult to capture, jumping into the water or hiding in rock crevices when disturbed. Inactive specimens were observed at night on leaves on low vegetation (up to $1.0 \mathrm{~m}$ above the ground) overhanging the stream, or within small crevices on the river margins.

Emerged rocks and logs are used for calling, courtship, and feeding activities. Both males and females are typical sit-and-wait strategists, resting most of the time on the emerged rocks awaiting the prey. They occasionally turn their body $45-90^{\circ}$ (a total of 171 occurrences performed by 29 males in one hour of observation; 109 occurrences performed by 13 females), move a few centimeters ahead, or to the side, on the same rock (65 occurrences by 19 males; 44 occurrences by 13 females), or jump to an emerged nearby rock (85 occurrences by 17 males; 60 occurrences by 13 females). When a prey is spotted, they chase it for a short distance (up to $3 \mathrm{~m}$ ) and return to the original place, sometimes to the same rock. Frogs preyed upon a number of different items such as small spiders, moths, cockroaches, flies, ants, beetles, and insect larvae.

Predators of Hylodes dactylocinus observed along the study were the colubrid snakes Xeno- don neuwiedi and an unidentified species of the genus Chironius. Xenodon neuwiedi preys upon small frogs (Jordão 1996), and the Chironius sp. was trying to catch a frog in the stream. It tried five times to catch the frog that easily jumped to another rock after each thrust given by the snake. Finally, the frog jumped into the water and stayed hidden, and the snake moved away. Other potential predators observed in the stream were birds, small mammals, snakes of the genera Bothrops and Spilotes, toads of the genus Bufo, spiders, crabs, and dragonfly larvae.

Males were acoustically active along the year but a peak of activity occurred in the dry season, from June to October (Figure 1). We observed a reduction of calling activities during heavy rains. The frequency of pregnant females was higher during winter. May was the month with the highest percentage of eggs in the females' oviducts (61.9\%), followed by July (57.7\%) and August (55.6\%) (Figure 1).

Thirteen females obtained in December 1995 were dissected and showed $46.2 \pm 7.9$ (mean \pm standard deviation) yellow eggs. The number of eggs in the right ovary $(28.8 \pm 5.7)$ was significantly higher than in the left one $(16.9 \pm$ 4.8) (Mann-Whitney, $p=0.01$ ). Two cohorts of juveniles were observed in October/November 1994 and November/December 1995 (mean $\mathrm{SVL}=19 \mathrm{~mm}$, and mean weight $=0.8 \mathrm{~g}$ at metamorphosis; $\mathrm{N}=24$ ). Thirty-two juveniles were recaptured after reaching sexual maturity, which is attained in about 6-7 months after metamorphosis. The average mensal growing rate for SVL was $1.56 \pm 1.01 \%(\mathrm{~N}=19)$ for males, and $1.97 \pm 0.81 \%(\mathrm{~N}=13)$ for females.

There was no significant difference between number of recaptures for individual males (11.4 $\pm 7.7)$ and females $(11.6 \pm 6.2)$ (Mann-Whitney $\mathrm{p}=0.739$ ). The maximum number of recaptures was 36 for a male, and 30 for a female; a total of 137 marked individuals (66.8\%) were recaptured at least once. The SVL of the adult males ranged from 24 to $27 \mathrm{~mm}(25.2 \pm 0.8$; $\mathrm{N}=$ $74)$, and from 25 to $31 \mathrm{~mm}(27.0 \pm 1.3 ; \mathrm{N}=63)$ in the adult females. The average monthly 


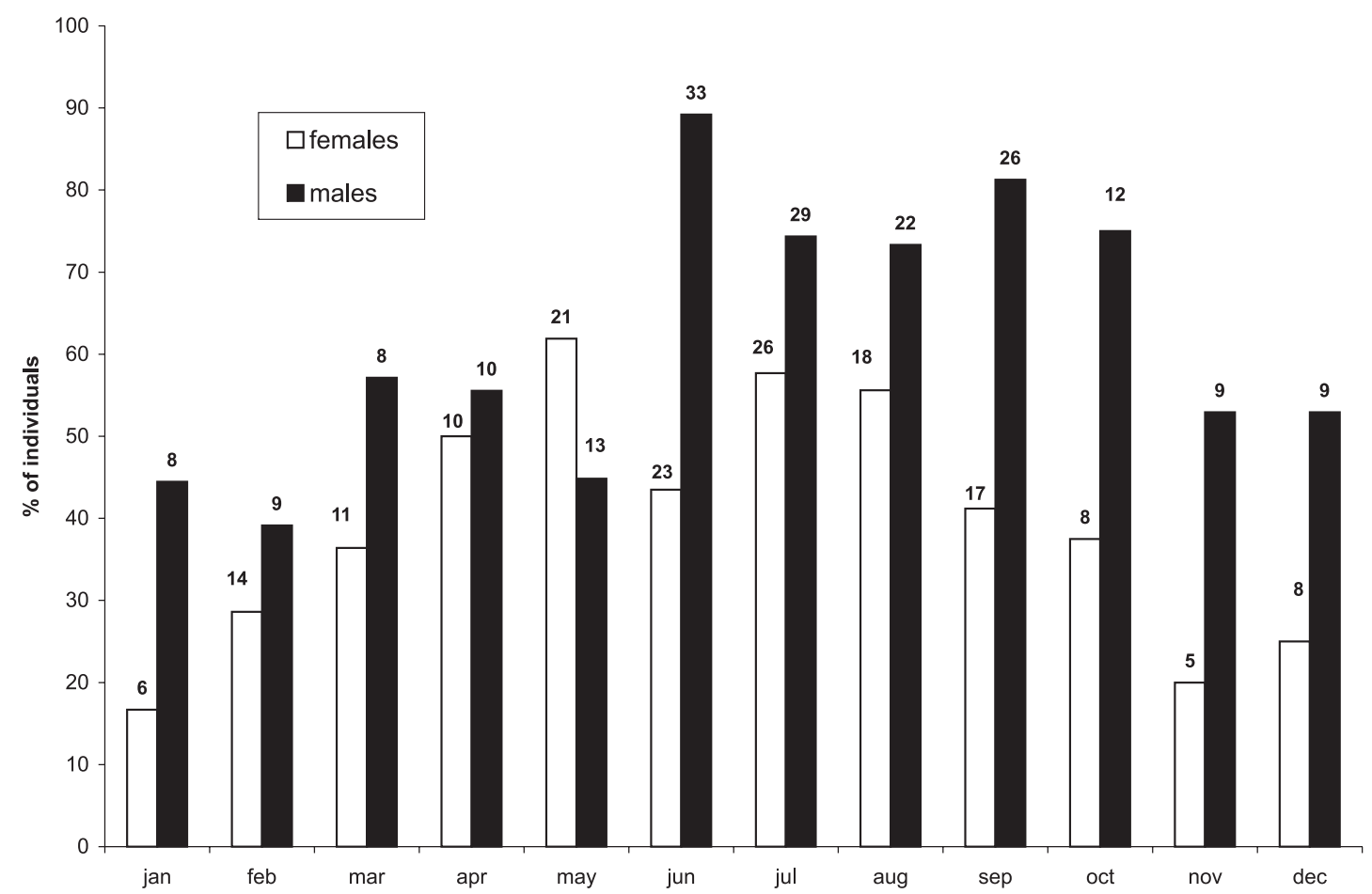

Figure 1 - Percentages of calling males and pregnant females of Hylodes dactylocinus in 1995 at the study area. The numbers over bars represent the total number of individuals analyzed by month.

density in the area studied was 1 individual per $7 \mathrm{~m}^{2}$ (or 14 individuals per $100 \mathrm{~m}^{2}$ ), and the sex ratio was 1.5 males to 1 female.

\section{Home Range}

Male home ranges varied from 0.12 to 13.12 $\mathrm{m}^{2}(\mathrm{~N}=44)$; and female home ranges varied from 0.45 to $7.98 \mathrm{~m}^{2}(\mathrm{~N}=24)$ (Figure 2). Home-range size of $56.8 \%$ of the males and $45.8 \%$ of the females varied from 0.1 to $2.0 \mathrm{~m}^{2}$; and $33.3 \%$ of the females and only $4.5 \%$ of the males have home range size varying from 3.0 to $4.0 \mathrm{~m}^{2}$. Males remained as residents in the same area from one to at least 12 months (mean 5.7 months); four and five months were the most frequent time spent in the same area (about 20\% of the males). Females were found in the same home range from two to 10 months (mean 6.1 months); six months was the most frequent time spent in the same area (about 29\% of the females). We observed a male spending five months within a home range of $2.53 \mathrm{~m}^{2}$ (12 recaptures), and then it apparently abandoned this area and moved four meters downstream to set another home range of $0.76 \mathrm{~m}^{2}$ (eight recaptures) for at least three months of residency.

There was no significant difference in home range size (Mann-Whitney, $\mathrm{p}=0.596$ ), and residence time (in months) $(\mathrm{p}=0.158)$ between males and females. Males showed a moderate positive correlation regarding home range size and number of recaptures (Pearson coefficient correlation, $r=0.733$; $\mathrm{p}<0.05$ ), a low positive correlation between home range size and time of residency $(r=0.447, p<0.05)$, and no significant correlation between home range size and SVL $(r=0.037, p>0.05)$, and between home 


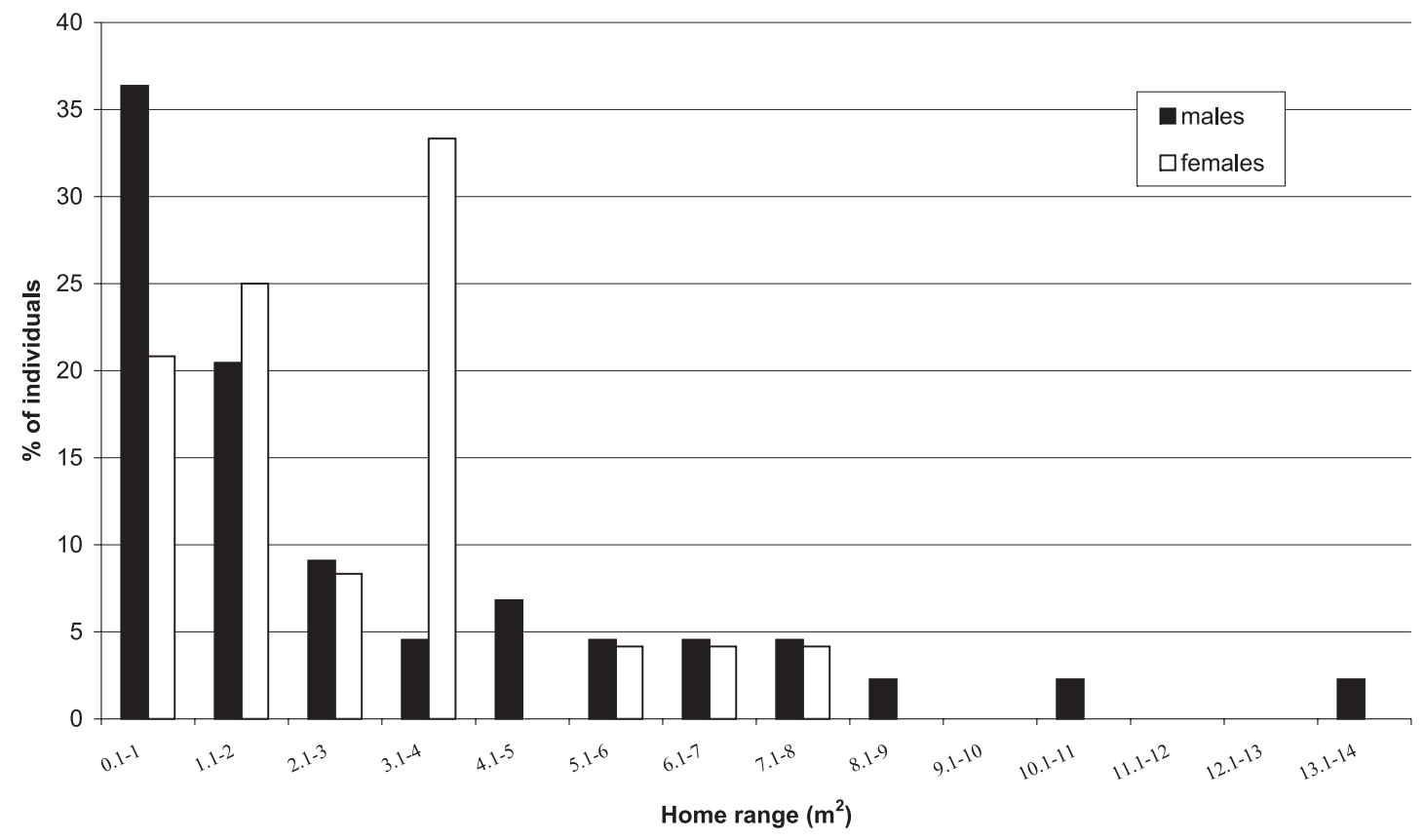

Figure 2 - Percentages of males and females of Hylodes dactylocinus within home range size classes at the study area.

range size and weigh $(\mathrm{r}=0.191, \mathrm{p}>0.05)$. Females showed no significant correlation between home range size and number of recaptures $(r=0.334, \mathrm{p}>0.05)$, between home range size and SVL $(r=0.099, \mathrm{p}>0.05)$, between home range size and time of residency $(r=-0.024, p>0.05)$, and between home range size and weigh $(r=0.188, \mathrm{p}>0.05)$.

Males and females showed a high fidelity to their home range. Three females moved 19, 25 and 32 meters upstream from their original home range to mate, and returned to their home range afterwards. The first female had a home range of $3.4 \mathrm{~m}^{2}$ (18 recaptures, in six months); the second female had a home range of $1.8 \mathrm{~m}^{2}$ (30 recaptures in 10 months), and the male she mated with had a home range of $10.6 \mathrm{~m}^{2}$ (24 recaptures, in five months); the third female had a home range of $0.9 \mathrm{~m}^{2}$ (10 recaptures, in seven months), and the male she mated with defended a home range of 1.6 $\mathrm{m}^{2}$ (13 recaptures, in five months).
Resident adult males did not tolerate the presence of other individuals in their territories and performed visual and acoustic displays to expel the intruder (see under Visual and Acoustic Signaling). Juveniles, however, were an exception. We frequently observed juveniles near resident adult males, and apparently they did not oppose a treat to the males and were not bothered or forced to leave the resident's territory. The resident male may use the differences in the coloration of adults and juveniles as a clue to identify the juveniles and thus preventing the loss of energy required to expel an intruder.

\section{Visual and Acoustic Signaling}

Males of Hylodes dactylocinus had two different calls: an advertisement call (a long, high-pitched whistled trill), and a close-range encounter call (an irregular number of squeaks) 
(Pavan et al. 2001). They also performed three conspicuous visual signals: foot-flagging, toewiggling, and leg-stretching.

In the foot-flagging movement, the hind leg was raised and stretched upward and backward at an angle of about $45^{\circ}$ from the substrate and then returned to its normal position (Figure 3). While the leg was extended, the toes of the opposite leg were slightly curled so the white upper surfaces were very conspicuous. The footflagging was usually performed during vocalization (advertisement call) (402 occurrences by 32 males), but also performed by males that were not calling (30 occurrences by 12 males). Foot flagging began either with the right or the left leg and followed no defined pattern; however, the frequency of movements starting with the right leg appears to be higher (in 19 frogs observed during one hour, foot-flagging began 150 times with the right leg vs. 132 times with the left leg). Vocalizations without footflagging were more frequent though (1094 occurrences by 34 males). Vocalization and foot-flagging were intensified when an intruder approached the male's territory. The resident usually moved towards the intruder, stood right in front of him, and increased the rate of the advertisement call and the foot-flagging behavior. In this position, the conspicuous white areas on the inner side of the thigh, and on the surfaces of the toes, became clearly evident.

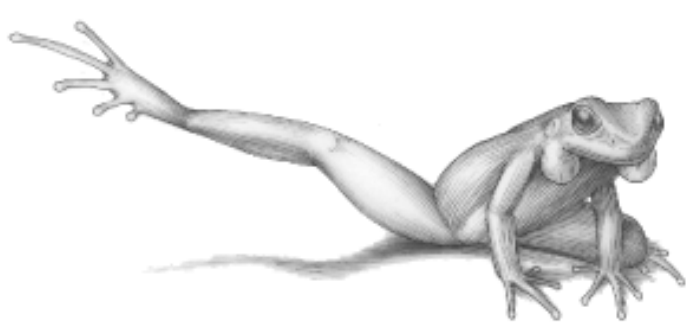

Figure 3 - A stereotyped male of Hylodes dactylocinus performing foot-flagging behavior, illustrated by R. Lupo after a video taken by M. T. Rodrigues at Arporador, EEJI, Brazil.
In the toe-wiggling display each toe was elevated and descended in sequence, starting with the external toe, and the toes were moved sequentially in a wave-like fashion, without otherwise moving the leg. The toe-wiggling display was not accompanied by vocalization and was given alternately with both feet (352 occurrences by 24 males). The brilliant dorsal white surface of the toes enhanced the visibility of the movement. This movement can be performed alone, as a primer for the foot-flagging behavior, or along with the leg-stretching movement.

In the leg-stretching movement, the stretched legs was quickly returned to its original positions, or remained stretched for a short time. In the latter case, the frog may perform toewiggling while the legs are stretched (Figure 4). Levels of stretching can also vary: the legs can be stretched completely or partially, with the tibia maintained at a right angle to the thigh. While the legs were stretched, the male can move forward using the forelegs (240 occurrences by 32 males), and may emit a closerange encounter call (five times by four males). As the frog moved forward, the hind legs were folded and stretched again, with a slight lift of the body upwards. The leg-stretching display was frequently performed in situations of closerange interactions (less than $3 \mathrm{~m}$ ) among individuals (138 occurrences by 29 males).

When two males interact for the possession of a territory they usually begin performing footflagging and emitting advertisement calls. If the intruder also vocalizes and displays footflagging the resident will move closer intensifying foot-flagging and vocalization. The intruder defended himself by kicking the opponent very quickly with one of the hind legs (11 occurrences by nine males). We observed an intruder male kicked a resident six times in about 30 seconds, but the resident did not move, and employed foot-flagging and calling until the intruder moved $3 \mathrm{~m}$ away. On some occasions, the resident tried to dislodge the intruder by standing under the opponent and raising the 

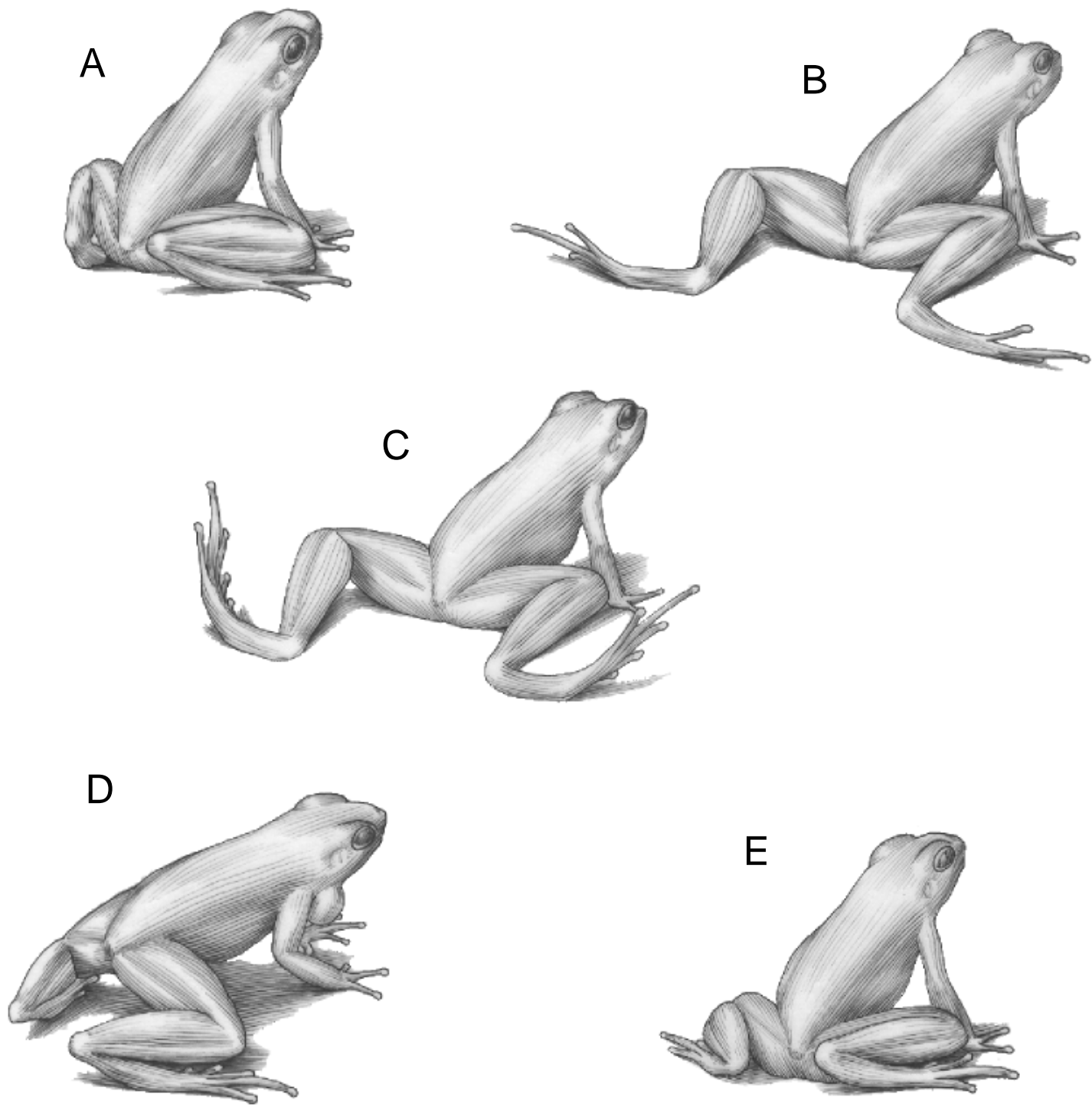

Figure 4 - The sequences of the leg-stretching movement performed by a stereotyped male of Hylodes dactylocinus, illustrated by R. Lupo after a video taken by M. T. Rodrigues at Arporador, EEJI, Brazil. The legs are extended in $\mathrm{B}$; the toes are wiggled in $\mathrm{C}$; the frog calls and raises the body in $\mathrm{D}$.

back of the body until the intruder moved away (22 occurrences by four males).

We also observed a subtle up-and-down movement of one of the arms performed by 10 males, from one to seven times, a total of 24 occurrences within one hour. The males seem to employ this movement with no apparent pattern. A similar movement was observed when the frog was swallowing a prey.

Females of Hylodes dactylocinus did not present the contrasting color pattern on the dorsal surface of the feet and the inner part of 
thigh, and were not observed performing footflagging, toe-wiggling or leg-stretching.

\section{Reproduction and Courtship}

Males of Hylodes dactylocinus dig underwater chambers prior to courtship and oviposition. The chambers were excavated on the sandy bottom between the small rocks, along the stream. We observed a male that spent 2 h 42 min excavating a chamber, using its forearms and hind legs. The male dove 33 times, and remained an average of 1.8 minutes under water (standard deviation, $\mathrm{SD}=1.0$ ); the average time between each dive was $2.3 \mathrm{~min}(\mathrm{SD}=1.0)$.

Courtship can be described as follows: when the male perceives an approaching female he faces her and starts to emit the advertisement calls plus foot-flagging displays; if the female does not leave, the male approaches the female and emits the encounter call, and then touches her snout with his snout two or three times; after touching the female, the male starts moving towards the nest located in his territory, followed by the female; the male stops once or twice during the way, turn back to the female and touches her snout again with his snout; the male dives in the flowing water and the female follows him underwater to the entrance of the previously dug nest; the male enters the nest first, followed by the female.

We observed 17 females being courted by males but only five did not flee during the courtship ritual. Two of the couples observed dove together and spent 14 and 19 min underwater but the oviposition did not occur. Three of the couples that actually oviposited spent 24,37 and 40 minutes, respectively, in the nest underwater. Amplexus was not observed but it presumably occurred inside the nest. The females were the first to leave the nest, and immediately returned to their own home range. Two females that were weighted before and after oviposition showed a decrease of 17 and 24\% in weight.

By using the forearms and legs, the males close the entrance of the nest, pushing sand and pebbles under water. In one occasion a male spent 20 minutes concealing the nest entrance. Once finished, the male remained on the emerged rocks near the nest, and employed advertisement call and toe-wiggling. We searched in one of the nests after oviposition and found an old and intact pelvic ring of the resident male along with white non-pigmented eggs. The male already had a new pelvic ring in place and may have lost the old one while digging the nest prior to oviposition or, while closing the entrance of the nest after a previous oviposition, what indicates that the same nest may be used more than once.

\section{Discussion}

\section{Home Range and Activity Pattern}

Males of Hylodes dactylocinus studied at the EEJI showed a peak of calling activity during the dry season (June-September) that agrees with the higher frequency of pregnant females observed in May-August. The cohort of juveniles observed in October to December seems to be clearly related to the peak of male activity and female pregnancy observed. This peak of activity seems also related to the time necessary to reach sexual maturity (about 6-7 months after metamorphosis). An opposite situation was observed for $H$. asper where the peak of activity for males was in the rainy season (October-March) (Haddad and Giaretta 1999). We have no answer to account for these divergences, but they may be due to the differences in the habitat occupied by both species. Hylodes asper is usually found in larger streams (deeper and wider, with many boulders), and with less protection against radiation, than $H$. dactylocinus. The effects of heavy rain on a smaller stream are considerably higher, the flooding is stronger and may cause more damages even to the underwater nests, and leave less emerged rocks to be used by the frogs as calling sites. Prolonged studies about $H$. asper (according to the authors, the study was 
conducted for 45 days), and studies of $H$. dactylocinus from other locations are necessary to clarify the differences in calling activity for both species.

Several anurans show home-range fidelity during the reproductive season. The permanent streams used by Hylodes dactylocinus, with food available throughout the year, afford homerange maintenance for longer periods of time. According to Crump (1988) the great advantage of keeping a specific home range relies on the fact that the resident will be able to feed and to escape more easily from predators in a known territory. This may be the case for the females of $H$. dactylocinus as their home range usually overlaps. For males, however, population density may influence the residence time by affecting food and nest availability. The population of $H$. dactylocinus studied had a density of 1 individual per $7 \mathrm{~m}^{2}$, and male homerange size varied from 0.12 to $13.12 \mathrm{~m}^{2}$. Defending a territory for as long as possible may be an advantage for a male in order to ensure the availability of food and good places for oviposition. Two of the males that mate with females had the biggest home-range size (10.57 and $13.12 \mathrm{~m}^{2}$ ), but the data is inconclusive to corroborate the idea that males with bigger home range are more successful than males with smaller ones.

The home-range size of anuran species can be related to a series of factors like seasonality, density of the population, size of individuals, availability of shelter and food, presence of mates and sites for vocalization and oviposition. Species living on the leaf litter can have bigger home ranges: e.g. Epipedobates femoralis from 0.25 to $26 \mathrm{~m}^{2}$ (Roithmair 1992), Eleutherodactylus fenestratus from 0.4 to $47.7 \mathrm{~m}^{2}$ (Schiesari 1996). Species living in streams are normally restricted to the riverbed and usually occupy smaller areas, e.g. Colostethus trinitatis from 0.3 to $1 \mathrm{~m}^{2}$ (Sexton 1960, Wells 1980b).

Males defending territories usually have smaller home ranges than non-territorial females (Wells 1980b). The analysis conducted showed no significant difference between the homerange size of males and females of $H$. dactylocinus, but we observed a higher frequency of females with larger home-ranges (33.3\% of the females presented home-range sizes varying from 3.0 to $4.0 \mathrm{~m}^{2}$ ), indicating a possible larger home range size for females than males.

\section{Visual Signaling}

Except for dendrobatid frogs, with 34 diurnal species performing some kind of visual signaling (Hödl and Amézquita 2001), the use of leg or hand movements as displays are rare among anurans and have been reported for a few species: Atelopus varius, A. limosus, A. chiriquiensis and A. zeteki, (Bufonidae) (Jaslow 1979, Crump 1988, Ibáñez et al. 1995, Lindquist and Hetherington 1996); Staurois parvus and S. latopalmatus (Ranidae) (Harding 1982, Davison 1984); Hylodes asper and $H$. dactylocinus (Leptodactylidae) (Heyer et al.1990, Hödl et al. 1997, Haddad and Giaretta 1999, Pavan et al. 2001); Crossodactylus gaudichaudi (Leptodactylidae) (Weygoldt and Carvalho e Silva 1992); Taudactylus eungellensis (Myobatrachidae) (Winter and McDonald 1986); Brachycephalus ephippium (Brachycephalidae) (Pombal et al. 1994); Litoria fallax, L. genimaculata, L. nannotis, and L. rheocola (Hylidae) (Richards and James 1992); Phyllomedusa burmeisteri (Haddad and Giaretta 1999; Bertoluci 2002), Phyllomedusa sauvagii (Hylidae) (Halloy and Espinosa 2000); and Dendropsophus parviceps (Hylidae) (Hödl and Amézquita 2001). Visual signaling is predicted to be employed by diurnal species (Endler 1992) but only a few behavioral studies have been carried out concerning this aspect, and therefore visual signaling as a significant mode of communication may be more common than currently documented (for a review and a classification of visual signaling see Hödl and Amézquita 2001 and Hartmann et al. 2005).

The context in which the visual signaling is performed by some species of anurans is not 
clear (Lindquist and Hetherington 1996). Displays are performed during courtship in Staurois (Harding 1982, Davison 1984), and during aggressive behavior in Phyllomedusa, Atelopus, Brachycephalus, and Litoria (Richards and James 1992, Pombal et al. 1994, Lindquist and Hetherington 1996, Halloy and Espinoza 2000). In Hylodes asper and $H$. dactylocinus the signaling is used during courtship interactions and in agonistic contexts to defend a territory (Heyer et al. 1990, Haddad and Giaretta 1999, this paper). The possible disadvantage of the signaling behavior - the enhancement of conspicuousness for predators - can be compensated by the facility of the frog to escape and hide when jumping into the flowing water (Hödl et al. 1997, Haddad and Giaretta 1999).

The hypotheses on the evolution of visual display in anurans have been associated with several aspects such as: ritualization of signals (Krebs and Davies 1993); locatability (Klump 1995); diurnality (Harper 1991); aposematic coloration (Duellman and Trueb 1986, Pombal et al. 1994); and ambient noise (Harper 1991). Diurnal species breeding near waterfalls (Atelopus, Hylodes, Staurois, and Taudactylus) could have evolved visual signaling because of the environmental noise, diurnality, and living in an open habitat such as a stream. To live in an open habitat may be an important feature to the evolution of visual signaling. As reported by Hödl and Amézquita (2001), except for the species that perform foot-flagging, almost all reported visual displays were preformed in close-range interactions, when individuals were less than $50 \mathrm{~cm}$ from one another. This may be the case with Hylodes phyllodes. This species lives in small secondary streams and less exposed than $H$. asper and $H$. dactylocinus (Heyer et al. 1990) and seem to perform signaling only before oviposition, i.e. in close range interactions (Pavan, pers. comm.). Other Hylodes species should be investigated further in order to have a better approach on the evolution of visual signaling in the genus.

\section{Courtship}

The complex courtship behavior observed in Hylodes dactylocinus may be associated with prolonged breeding, diurnality, and males and females living in the same habitat. In this situation, a number of acoustic, tactile and visual signals can evolve to facilitate communication among males and females, increasing the complexity of courtship behaviors (Wells 1977a, b). Long interactions between males and females may have the purpose of evaluating the condition of the mate, triggering ovulation, and leading the female from the calling site to the nest (Hartmann et al. 2004). The distance from the calling site to the nest may be an important factor involved in the evolution of the courtship behavior in Hylodes dactylocinus.

The underwater chamber previously excavated by the males provides protection against predators during the early development of the embryo, and prevents eggs from drifting in the flowing water. The large number of eggs produced by the females (mean 46.2) can be associated with habitat conditions: the tadpoles can be highly predated in an aquatic environment (Duellman and Trueb 1986), and intensified rains can drift some of the hidden eggs, especially in small streams as it is the case with the population of $H$. dactylocinus studied. A relatively large number of eggs increase the reproductive success when there is no parental care except for the concealing nest behavior of males reported in this paper.

The reproductive behavior of Hylodes dactylocinus is similar in some aspects to those of Crossodactylus gaudichaudii (Weygoldt and Carvalho e Silva 1992), Hylodes asper (Haddad and Giaretta 1999) and $H$. phyllodes (Faria et al. 1993) in which oviposition also takes place in an underwater chamber dug by the male. Concealing the nest entrance, however, was observed only for C. gaudichaudii, based on observations of captive animals (Weygoldt and Carvalho e Silva 1992), and only $H$. asper has been reported to employ conspicuous visual 
signaling displays, e.g. foot-flagging (Heyer et al. 1990, Hödl et al. 1997, Haddad and Giaretta 1999). Signaling behavior and elaborate courtship appear to be constant characteristics among some species of the subfamily Hylodinae, for which we strongly suggest further comparative studies.

\section{Acknowledgements}

We thank Instituto Florestal and Rosely Sanches for permission to visit and work at the Estação Ecológica Juréia-Itatins; V. K Verdade, L. F. Silveira, D. Pavan, W. R. Heyer, and W. Hödl for critically reading the manuscript; V. X. Silva, M. Cox, J. C. Passoni, D. Pavan, C. Jared, F. Franco, A. A. Silva, and A. M. Santos for assistance in the field. PN acknowledges FAPESP (94/3189-4) for financial support and CNPq for a graduate fellowship.

\section{References}

Altman, J. 1974. Observational study of behavior: sampling methods. Behavior 49: 227-265.

Bertoluci, J. 2002. Pedal luring in the leaf-frog Phyllomedusa burmeisteri (Anura, Hylidae, Phyllomedusinae). Phullomedusa 1: 93-95.

Dubois, A. 2005. Amphibia mundi 1.1. An ergotaxonomy of recent amphibians. Alytes 23: 1-24.

Crump, M. L. 1988. Aggression in harlequin frogs: malemale competition and a possible conflict of interest between the sexes. Animal Behaviour 36: 1064-1077.

Davison, G. 1984. Foot flagging displays in Bornean frogs. Sarawak Museum Journal 33: 177-178.

Duellman, W. E. and L. Trueb. 1986. Biology of Amphibians. New York. McGraw-Hill Book Co. 670 pp.

Endler, J. A. 1992. Signals, signal conditions, and the direction of evolution. American Naturalist 139: S125-S153.

Faria, D. M., L. L. Casais e Silva and M. T. Rodrigues. 1993. Nota sobre a reprodução de Hylodes phyllodes (Anura: Leptodactylidae). Resumos do III Congresso Latino Americano de Herpetologia, Campinas, SP, Brazil.

Frost, D. R. (ed.). 2004. Amphibian Species of the World: an online reference. Version 3.0. URL: http:// research.amnh.org/herpetology/amphibia/index.php. Captured on 4 April 2005.

Gouvêa, E. 1979. Uma nova espécie de Elosiíneo da Serra do Itatiaia (Amphibia, Anura, Leptodactylidae). Revista Brasileira de Biologia 39: 855-859.

Haddad, C. F. B. and A. A. Giaretta. 1999. Visual and acoustic communication in the Brazilian torrent frog, Hylodes asper (Anura: Leptodactylidae). Herpetologica 55: 324-333.

Haddad, C. F. B. and J. P. Pombal Jr. 1995. A new species of Hylodes from Southeastern Brazil (Amphibia: Leptodactylidae). Herpetologica 51: 279-286.

Haddad, C. F. B., J. P. Pombal Jr and R. P. Bastos. 1996. New species of Hylodes from the Atlantic Forest of Brazil (Amphibia: Leptodactylidae). Copeia 1996: 965-969.

Halloy, M. and R. E. Espinoza. 2000. Territorial encounters and threat displays in the Neotropical frog Phyllomedusa sauvagii (Anura: Hylidae). Herpetological Natural History 7: 175-180.

Harding, K. A. 1982. Courtship display in a Bornean frog. Proceedings of the Biological Society of Washington 95: 621-624.

Harper, D. G. C. 1991. Communication. Pp. 374-397 in J. R. Krebs and N. B. Davies (eds.), Behavioural Ecology: an evolutionary approach. Sunderland and Massachusetts. Sinauer.

Hartmann, M T., P. A. Hartmann and C. F. B. Haddad. 2004. Visual signaling and reproductive biology in a nocturnal treefrog genus Hyla (Anura: Hylidae). Amphibia-Reptilia 25: 395-406.

Hartmann, M T., L. O. M. Giasson, P. A. Hartmann, and C. F. B. Haddad. 2005. Visual communication in Brazilian species of anurans from the Atlantic Forest. Journal of Natural History 39: 1675-1685.

Hatano, F. H., C. F. D. Rocha and M. Van Sluys. 2002. Environmental factors affecting calling activity of a tropical diurnal frog (Hylodes phyllodes: Leptodactylidae). Journal of Herpetology 36: 314-318.

Hero, J. M. 1989. A simple code for toe clipping anurans. Herpetological Review 20: 66-67.

Heyer, W. R., A. S. Rand, C. A. G. Cruz, O. L. Peixoto, and C. E. Nelson. 1990. Frogs of Boracéia. Arquivos de Zoologia, São Paulo 31: 231-410.

Hödl, W. and A. Amézquita. 2001. Visual signaling in anuran amphibians. Pp. 121-141 in M. Ryan (ed.), Anuran Communication. Smithsonian Institution Press, Washington.

Hödl, W., M. T. Rodrigues, G. M. Accacio, P. H. Lara, D. Pavan, L. C. Schiesari, and G. Skuk. 1997. Foot flagging behavior in Hylodes asper (Leptodactylidae). Scientif film, Ctf 2444 ÖWF, Vienna, Austria. 
Ibáñez, R. D., A. Jaramillo and F. A. Solís. 1995. Una nueva especie de Atelopus (Amphibia: Bufonidae) de Panama. Caribbean Journal of Science 31: 57-64.

Jaslow, A.P. 1979. Vocalization and aggression in Atelopus chiriquensis (Amphibia, Anura, Bufonidae). Journal of Herpetology 13: 141-145.

Jordão, R. S. 1996. Estudo comparativo da alimentação e reprodução de Waglerophis merremii e de Xenodon neuwiedii (Serpentes: Colubridae). Unpublished M.Sc. Dissertation. Universidade de São Paulo, Brazil.

Klump, G. M. 1995. Studying sound localization in frogs with behavioral methods. Pp. 221-233 in G. M. Klump, R. J. Dooling, R. R. Fay, and W. C. Stebbins (eds.), Methods in Comparative Psychoacoustics. Basel. Birkhäuser Verlag.

Krebs, J. R. and N. B. Davies. 1993. An Introduction to Behavioral Ecology. London. Blackwell Scientific Publications.

Lehner, P. N. 1979. Handbook of Ethological Methods. New York. Garland STPM Press. 403 pp.

Lindquist, E. D. and T. E. Hetherington. 1996. Field studies on visual and acoustic signaling in the "earless" Panamanian golden frog Atelopus zeteki. Journal of Herpetology 30: 347-354.

Mohr, C.O. 1947. Table of equivalent populations of North American small mammals. American Midland Naturalist, 37: 223-249.

Narvaes, P. 1997. Comportamento territorial e reprodutivo de uma nova espécie de Hylodes (Amphibia, Anura, Leptodactlidae) da Mata Atlântica do Sudeste do Brasil. Unpublished M.Sc. Dissertation. Universidade de São Paulo, Brazil. [available for download at http:// www.teses.usp.br].

Pavan, D., P. Narvaes and M. T. Rodrigues. 2001. A new species of a leptodactylid frog from the Atlantic Forest of Southeastern Brazil with notes on the status and on the speciation of the Hylodes species groups. Papéis Avulsos de Zoologia, São Paulo 41: 405-423.

Pombal Jr, J. P., I. Sazima and C. F. B. Haddad. 1994. Breeding behavior of the pumpkin toadlet Brachycephalus ephippium (Brachycephalidae).
Journal of Herpetology 28: 516-519.

Richards, S. J. and C. James. 1992. Foot flagging displays of some Australian frogs. Memoirs of the Queensland Museum 32: 302.

Roithmair, M. E. 1992. Territoriality and male mating success in the dart-poison frog, Epipedobates femoralis (Dendrobatidae, Anura). Ethology 92: 331-343.

Schiesari, L. C. 1996. Territorialidade em Eleutherodactylus fenestratus (Steindachner) (Amphibia; Anura; Leptodactylidae). Unpublished M.Sc. Dissertation. Universidade de São Paulo, Brazil.

Sexton, O. J. 1960. Some aspects of the behavior and of the territory of a dendrobatid frog Prostherapis trinitatis. Ecology 41: 107-115.

Wells, K. D. 1977a. The social behavior of anuran amphibians. Animal Behaviour 25: 666-693.

Wells, K. D. 1977b. The courtship of frogs. Pp. 233-262 in D. H. Taylor and S. I. Guttman (eds.), The Reproductive Biology of Amphibians. New York. Plenum Press.

Wells, K. D. 1980a. Behavioral ecology and social organization of a dendrobatid frog (Colostethus trinitatis). Behavioral Ecology and Sociobiology 6: 199-209.

Wells, K. D. 1980b. Social behavior and communication of a dendrobatid frog (Colostethus trinitatis). Herpetologica 36: 189-199.

Weygoldt, P. and S. P. Carvalho e Silva. 1992. Mating and oviposition in the hylodine frog Crossodactylus gaudichaudii (Anura: Leptodactylidae). AmphibiaReptilia 13: 35-45.

Winter, J. and K. McDonald. 1986. Eungella: The land of the cloud. Astralian Natural History 22: 39-43.

Zar, J.H. 1999. Biostatistical Analysis. $4^{\text {th }}$ ed. Upper Saddle River. Prentice-Hall, Inc. 931 pp.

Zimmermann, H. and E. Zimmermann. 1988. Ethotaxonomie und zoogeographische Artengruppenbildung bei Pfeilgiftfröschen (Anura: Dendrobatidae). Salamandra 24: 125-160. 